\title{
Short Communication: The tolerance level of local sorghum genotypes from Sabu-Raijua and Belu Districts, Indonesia to saline soil
}

\author{
YOKE. I. BENGGU ${ }^{1, \vartheta}$, ELIAS ST. O. NGURU ${ }^{1}$ \\ ${ }^{1}$ Department of Agrotechnology, Faculty of Agriculture, Universitas Nusa Cendana, Jl. Adisucipto, Penfui, Kupang 85148, East Nusa Tenggara, \\ Indonesia. Tel./fax.: +62-380-881085, `email: yokebenggu@ ymail.com
}

Manuscript received: 14 September 2017. Revision accepted: 27 April 2018.

\begin{abstract}
Benggu YI, Nguru ESO. 2018. The tolerance level of local sorghum genotypes from Sabu-Raijua and Belu Districts, Indonesia to saline soil. Trop Drylands 2: 1-4. Sorghum is potential agricultural crop developed in semi-arid region in Indonesia which is characterized by dry climate and saline soil. This study aimed to determine the level of tolerance of local sorghum from Sabu-Raijua and Belu Districts, Nusa Tenggara Timur Province to saline soil. The research was conducted in the experimental field and soil chemistry laboratory of Faculty of Agriculture, Universitas Nusa Cendana, from June to October 2016. The study was carried out in a factorial treatment design laid out in a completely randomized design with two factors. The first factor was the variety of sorghum, consisting of three levels: local sorghum from Sabu-Raijua, local sorghum from Belu and national Numbu variety. The second factor was the salinity levels of Vertisol, composed of five levels, i.e., $0,6,8,10$ and 12 mmos.cm ${ }^{-1}$. In total, there were 15 treatments with three replications for each treatment. Variables observed were plant height, number of leaves, flowering date, and seed dry weight. Analysis of variance was conducted followed by Tukey test (5\%). The result showed that there was an interaction effect between sorghum variety and salinity level of soil on all variables observed. In general, all varieties of sorghum grew normally with soil salinity level ranging from 0 to $8 \mathrm{mmos} . \mathrm{cm}^{-1}$. At salinity level of 8 to $12 \mathrm{mmos} . \mathrm{cm}^{-1}$, seedlings grew for a few weeks then gradually wilted and died. Local sorghum from Belu and national Numbu variety were semi or moderately tolerant to salinity while local sorghum from Sabu-Raijua was sensitive.
\end{abstract}

Keywords: Local sorghum, Sabu-Raijua, Belu, Numbu, salinity

\section{INTRODUCTION}

Dryland agriculture is an agro-ecological system promoted in the semi-arid region in Indonesia, including in the Province of East Nusa Tenggara (Nusa Tenggara Timur; NTT). The semi-arid climatic type is characterized by erratic and limited rainfall, high temperature and the slopping-dominant topographical area. Under these conditions, one of the main problems is the existing saline soil, because the amount of precipitation and surface water is not enough to wash out the salt from the topsoil. Saline soil in the context of crop cultivation, is soil which has DHL $>4$ mmos.cm ${ }^{-1}$ and soil $\mathrm{pH}<8.5$ at $25^{\circ} \mathrm{C}$ (Tan 1998). This high concentration of salt causes high osmotic pressure in the plant cell, making it difficult to absorb water and nutrients for plant growth.

In Indonesia, the saline soils are known to be mostly present in NTT Province, especially in the island of Timor (Darmawijaya 1990) with the distribution of saline soil is formed in large coastal areas (Kleden 1995 in Batha 2003). The influence of salinity has become increasingly serious, both in the context of intensity and extensification, due to global warming that causes sea levels to rise. As a result, most of the productive agricultural lands, especially those located in the coastal zone, will be affected by salinity.

Utilization of agricultural land affected by salinity can be done through various approaches, such as leaching out the salt using irrigation water and drainage improvement, treating soil surface to facilitate salt leaching, using gypsum to exchange sodium ions with calcium in the soil, using organic fertilizers to improve soil structure and percolation, as well as using plants that are tolerant or semi-tolerant to salinity (FAO 1985).

In the dryland agricultural community of NTT, sorghum has traditionally been one of the preferred cultivated crops. It is one of the relatively adaptive cereals to marginal growth factors, i.e., low soil fertility and water availability, as compared to other cereal crops such as rice and maize. Sorghum is known to have resistance to drought with water requirements of $300-400 \mathrm{~mm}$ during the growing period, resistant to waterlogging and high salinity and aluminum poisoning (House 1985; FAO 2001; Siregar et al. 2016). Also, the nutritional composition of the sorghum grain is not substantially different from corn and rice, making it an alternative to substituting staple food. In 2013, the Agency for Agricultural Research and Development released 11 superior varieties of sorghum to be developed in Indonesia, including NTT as one of the regional development of sorghum in eastern Indonesia. Nonetheless, the development of sorghum cultivation in NTT Province has been hampered because the government attempted to displace this crop with other cereal commodities, such as corn and rice, through intensification and extensification programs. 
To utilize saline soil in dryland agricultural ecosystems through the cultivation of tolerant and semi-tolerant plants, including sorghum, it is necessary to identify and determine the species or varieties of sorghum that are tolerant to salinity. There are various types of local superior sorghum varieties with different genotypes recommended to be developed in NTT Province. This type of local sorghum can be regarded as one of the local biological resources to be maintained and improved, as it is a type of sorghum that has been well adapted and proven to exist for long periods in the typical dryland ecosystem of NTT which become the comparative advantage. The local sorghum from Sabu-Raijua District, Terrae meddi, for example, has distinctive features such as the size of stems, leaves, large panicles, dark brown and mild orange seed, and flat oval-shaped seed. The agroecosystem condition in this region is dry and hot with average annual rainfall of $1,290 \mathrm{~mm}$, average wind speed of $8 \mathrm{knots}$, and $86.5 \%$ of solar irradiance (BPS Sabu-Raijua 2013). The local sorghum from Belu District, Batar ainaruk, has ovalshaped dark brown seeds. Belu has an annual rainfall of $1,127 \mathrm{~mm}$, average wind speed of 6 knots, and $80 \%$ of solar irradiance. Some areas in Belu have altitudes of up to $380 \mathrm{~m}$ above sea level (BPS Belu 2012). The present study was carried to determine the tolerance level of these local sorghum genotypes to saline soil.

\section{MATERIALS AND METHODS}

This research was out in the experimental field, and Soil Chemistry Laboratory, Faculty of Agriculture, Universitas Nusa Cendana, Kupang, Indonesia from June to October 2016.

This experiment was arranged in a Completely Randomized Design with a factorial treatment design consisting of two factors, i.e., local sorghum genotypes and level of soil salinity. The first factor consisted of three sorghum genotypes, i.e., (S1): Local sorghum from SabuRaijua District, (S2): Local sorghum from Belu District, and (S3): the national check variety Numbu. The second factor consisted of five salinity levels, i.e., (G1): 0 mmos.cm-1, (G2): 6 mmos.cm ${ }^{-1},(\mathrm{G} 3): 8$ mmos.cm ${ }^{-1}$ (G4): 10 mmos.cm ${ }^{-1}$, (G5): 12 mmos.cm ${ }^{-1}$. Each treatment comprised of three replications

Sorghum seeds were planted in polybags according to the assigned treatment. It was done by immersing 3-5 seeds into the soil. At two weeks after planting (WAP), the seedlings were thinned out leaving only one plant per polybag. Watering was done homogeneously. The amount of water given was based on the plant water requirement while keeping the soil salinity level relatively unaffected. Weed, pests, and pathogens were controlled as needed.

Analysis of Variance (ANOVA) was performed to analyze the sorghum's tolerance response to salinity treatments. The following variables were observed: plant height, number of leaves, flowering date, and dry seed weight. The means of the different treatments were compared using Tukey Test (Montgomery 2012).

\section{RESULTS AND DISCUSSION}

In general, all sorghum varieties grew well on saline Vertisol soil. All seeds germinated and grew well with relatively normal and fairly good seedlings. The ability of sorghum seeds to germinate and grow into seedlings, presumably as a result of irrigation that was regularly (daily) provided homogeneously through surface precipitation. The water leached the salt on the surface layer, moving it toward the bottom layer due to water gravity. As a result, there was a decrease in the level of salinity on the surface zone to a level of salinity that still allowed the seeds to germinate. A similar result was stated by Hasanah et al. (2010) that dissolving salt in the soil at the beginning of the planting did not affect the further growth of the plant due to leaching caused by watering/irrigation.

In subsequent developments, there was an inhibition of the sorghum growth and its effects significantly varied depending on the different salinity level treatments. Even before the plants were entering the generative phase, characterized by the formation and development of panicles, some sorghum genotypes became dry (permanently wilted) and died, especially those treated with high salinity levels (10 and $\left.12 \mathrm{mmos} . \mathrm{cm}^{-1}\right)$. This condition occurred due to the root penetration reaching the accumulated layer of salt in the middle and bottom of the growing medium. The effects of salinity stress observed in the present study was similar to the effects of drought, where the plants grown in saline soil will react by showing permanent wilting symptoms and then dry out.

ANOVA analysis showed significant interaction effect between sorghum genotype and salinity level on plant height and number of sorghum leaves. The results showed that salinity level treatments markedly determined variations of plant height and number of leaves. The ANOVA results for plant height and number of leaves at eight weeks after planting (WAP) are presented in Table 1 while the mean of plant height and the number of leaves are presented in Table 2 .

Table 2 shows that the plant height and the number of sorghum leaves decreased along with the increase of soil salinity. In all sorghum genotypes, plant height and the number of leaves were higher in soil with a salinity level of 0 to $8 \mathrm{mmos} \mathrm{cm}^{-1}$ as compared to that of $10-12 \mathrm{mmos} \mathrm{cm}^{-1}$. The decrease in plant height and the number of leaves in the soil with a salinity level of $10-12 \mathrm{mmos} \mathrm{cm}^{-1}$ may be one of the mechanisms of the plant to tolerate the presence of salt by reducing the growth components that in turn will decrease the transpiration rate (Hasanah 2010). All plants were dead at a salinity level of $12 \mathrm{mmos} \mathrm{cm}^{-1}$. It is most likely that the toxic effects of salt-generating ions and the high pressure of osmosis media caused the plants could not be able to absorb water properly.

ANOVA results showed significant interaction effect between sorghum genotype and salinity level on the flowering date and dry seed weight of sorghum. It showed that variations of flowering age and dry seed weight were markedly determined by the salinity level treatment. The ANOVA results for flowering date and dry seed weight can 
be seen in Table 3 . The mean flowering date and dry seed weight are shown in Table 4.

Table 1. ANOVA results of plant height and number of leaves at eight weeks after planting on Vertisol soil with a different salinity level

\begin{tabular}{lccccc}
\hline \multirow{2}{*}{$\begin{array}{c}\text { Source of } \\
\text { variation }\end{array}$} & DF & \multicolumn{2}{c}{ Plant height } & \multicolumn{2}{c}{$\begin{array}{c}\text { Number of } \\
\text { leaves }\end{array}$} \\
\cline { 3 - 6 } & & $\begin{array}{c}\text { Mean } \\
\text { Square }\end{array}$ & Sig. & $\begin{array}{c}\text { Mean } \\
\text { Square }\end{array}$ & Sig. \\
\hline Sorghum & 2 & 12699.198 & $0.000^{* *}$ & 19.622 & $0.198^{\mathrm{ns}}$ \\
$\begin{array}{l}\text { genotype (S) } \\
\text { Salinity level (G) }\end{array}$ & 4 & 104.318 & $0.607^{\mathrm{ns}}$ & 472.144 & $0.000^{* *}$ \\
S x G & 8 & 583.315 & $0.018^{*}$ & 32.011 & $0.020^{*}$ \\
CV & & 28.99 & & 36.14 & \\
\hline
\end{tabular}

Note: $\mathrm{DF}=$ Degree of Freedom, CV = Coefficient of Variation **Highly significant effect $(\mathrm{P}<0.01),{ }^{\mathrm{ns}}$ no significant effect $(\mathrm{P}>0.05)$.

Table 2. Mean number of plant height and number of sorghum leaves (8 WAP) planted on Vertisol soil with a different salinity level

\begin{tabular}{|c|c|c|c|}
\hline $\begin{array}{l}\text { Sorghum } \\
\text { genotype }\end{array}$ & Salinity level & $\begin{array}{l}\text { Plant height } \\
\left(\mathrm{cm}^{*}\right)\end{array}$ & $\begin{array}{l}\text { Number of } \\
\text { leaves") }\end{array}$ \\
\hline Local Belu & $\begin{array}{l}0 \text { mmos } \mathrm{cm}^{-1} \\
6 \mathrm{mmos} \mathrm{cm}^{-1} \\
8 \mathrm{mmosn} \mathrm{cm}^{-1} \\
10 \mathrm{mmos} \mathrm{cm}^{-1} \\
12 \mathrm{mmos} \mathrm{cm}^{-1} \\
\text { Mean }\end{array}$ & $\begin{array}{l}81.00 \mathrm{c}^{*} \\
65.83 \mathrm{bc} \\
47.83 \mathrm{bc} \\
39.00 \mathrm{~b} \\
0.00 \mathrm{a} \\
46.73\end{array}$ & $\begin{array}{l}15.33 \mathrm{de} \\
14.00 \mathrm{~cd} \\
10.33 \mathrm{bc} \\
6.33 \mathrm{~b} \\
0.00 \mathrm{a} \\
9.20\end{array}$ \\
\hline $\begin{array}{l}\text { Local Sabu- } \\
\text { Raijua }\end{array}$ & $\begin{array}{l}0 \mathrm{mmos} \mathrm{cm}^{-1} \\
6 \mathrm{mmos} \mathrm{cm}^{-1} \\
8 \mathrm{mmos} \mathrm{cm}^{-1} \\
10 \mathrm{mmos} \mathrm{cm}^{-1} \\
12 \mathrm{mmos} \mathrm{cm}^{-1} \\
\text { Mean }\end{array}$ & $\begin{array}{l}84.67 \mathrm{~b} \\
81.00 \mathrm{~b} \\
81.33 \mathrm{~b} \\
0.00 \mathrm{a} \\
1.83 \mathrm{a} \\
49.77\end{array}$ & $\begin{array}{l}17.00 \mathrm{c} \\
9.33 \mathrm{~b} \\
14.33 \mathrm{c} \\
0.00 \mathrm{a} \\
1.00 \mathrm{a} \\
8.33\end{array}$ \\
\hline Numbu & $\begin{array}{l}0 \text { mmos cm } \\
6 \mathrm{mmos} \mathrm{cm}^{-1} \\
8 \mathrm{mmos} \mathrm{cm}^{-1} \\
10 \mathrm{mmos} \mathrm{cm}^{-1} \\
12 \mathrm{mmos} \mathrm{cm}^{-1} \\
\text { Mean }\end{array}$ & $\begin{array}{l}85.67 \mathrm{~b} \\
81.33 \mathrm{~b} \\
77.93 \mathrm{~b} \\
15.00 \mathrm{a} \\
0.00 \mathrm{a} \\
51.99\end{array}$ & $\begin{array}{l}15.00 \mathrm{~b} \\
14.67 \mathrm{~b} \\
21.00 \mathrm{c} \\
2.33 \mathrm{a} \\
0.00 \mathrm{a} \\
10.60\end{array}$ \\
\hline $\begin{array}{l}\text { Grand mean } \\
\text { Tukey test } 5\end{array}$ & & $\begin{array}{l}49.49 \\
33.98 \\
\end{array}$ & $\begin{array}{l}9.38 \\
4.54 \\
\end{array}$ \\
\hline
\end{tabular}

Table 3. ANOVA results of flowering date and dry seed weight of sorghum genotypes grown on Vertisol soil with a different salinity level

\begin{tabular}{|c|c|c|c|c|c|}
\hline \multirow{2}{*}{$\begin{array}{l}\text { Source of } \\
\text { variation }\end{array}$} & \multirow[b]{2}{*}{ DF } & \multicolumn{2}{|c|}{ Flowering date } & \multicolumn{2}{|c|}{ Seed dry weight } \\
\hline & & $\begin{array}{l}\text { Mean } \\
\text { Square }\end{array}$ & Sig. & $\begin{array}{l}\text { Mean } \\
\text { Square }\end{array}$ & Sig. \\
\hline $\begin{array}{l}\text { Sorghum } \\
\text { genotype (S) }\end{array}$ & 2 & 7110.600 & $0.000^{* *}$ & 301.963 & $0.000^{* *}$ \\
\hline Salinity level (G) & 4 & 5936.256 & $0.000^{* *}$ & 511.395 & $0.000^{* *}$ \\
\hline$S \times G$ & 8 & 2940.989 & $0.000^{* * *}$ & 132.278 & $0.000^{* *}$ \\
\hline CV & & 6.80 & & 38.10 & \\
\hline
\end{tabular}

Note: $\mathrm{DF}=$ Degree of Freedom, $\mathrm{CV}=$ Coefficient of Variation $* *$ Highly significant effect $(\mathrm{P}<0.01)$.
Table 4. Means of flowering date and dry seed weight of sorghum genotypes grown on Vertisol soil with different salinity level.

\begin{tabular}{|c|c|c|c|}
\hline $\begin{array}{l}\text { Sorghum } \\
\text { genotype }\end{array}$ & Salinity levels & $\begin{array}{l}\text { Flowering } \\
\text { date (days) }\end{array}$ & $\begin{array}{l}\text { Dry seed weight } \\
\left.\left(\text { g plant }^{-1}\right)^{*}\right)\end{array}$ \\
\hline \multirow[t]{6}{*}{ Local Belu } & 0 mmos. $\mathrm{cm}^{-1}$ & $70.67 \mathrm{a}^{*}$ & $19.00 \mathrm{~d}$ \\
\hline & 6 mmos. $\mathrm{cm}^{-1}$ & $75.00 \mathrm{ab}$ & $11.10 \mathrm{bc}$ \\
\hline & 8 mmos.cm ${ }^{-1}$ & $74.33 \mathrm{ab}$ & $5.58 \mathrm{~b}$ \\
\hline & 10 mmos.cm ${ }^{-1}$ & $79.00 \mathrm{ab}$ & $0.00 \mathrm{a}$ \\
\hline & 12 mmos.cm ${ }^{-1}$ & $81.67 \mathrm{~b}$ & $0.00 \mathrm{a}$ \\
\hline & Mean & 76.13 & 7.14 \\
\hline Local Sabu- & 0 mmos. $\mathrm{cm}^{-1}$ & $85.00 \mathrm{~b}$ & $0.00 \mathrm{a}$ \\
\hline \multirow[t]{5}{*}{ Raijua } & $6 \mathrm{mmos} . \mathrm{cm}^{-1}$ & $84.67 \mathrm{~b}$ & $0.00 \mathrm{a}$ \\
\hline & 8 mmos.cm ${ }^{-1}$ & $0.00 \mathrm{a}$ & $0.00 \mathrm{a}$ \\
\hline & $10 \mathrm{mmos}^{\mathrm{cm}} \mathrm{cm}^{-1}$ & $0.00 \mathrm{a}$ & $0.00 \mathrm{a}$ \\
\hline & 12 mmos.cm ${ }^{-1}$ & $0.00 \mathrm{a}$ & $0.00 \mathrm{a}$ \\
\hline & Mean & 33.93 & 0.00 \\
\hline \multirow[t]{6}{*}{ Numbu } & 0 mmos. $\mathrm{cm}^{-1}$ & $82.67 \mathrm{c}$ & $13.90 \mathrm{~b}$ \\
\hline & 6 mmos. $\mathrm{cm}^{-1}$ & $70.33 \mathrm{~b}$ & $23.50 \mathrm{c}$ \\
\hline & 8 mmos.cm ${ }^{-1}$ & $75.67 \mathrm{~b}$ & $20.47 \mathrm{c}$ \\
\hline & 10 mmos.cm ${ }^{-1}$ & $0.00 \mathrm{a}$ & $0.00 \mathrm{a}$ \\
\hline & 12 mmos.cm ${ }^{-1}$ & $0.00 \mathrm{a}$ & $0.00 \mathrm{a}$ \\
\hline & Mean & 45.73 & 11.57 \\
\hline Grand mean & & 51.93 & 6.24 \\
\hline Tukey test 5 & & 8.37 & 5.63 \\
\hline
\end{tabular}

Tukey test $5 \%$

8.37

5.63

"Numbers within a column followed by different letters are significantly $(\mathrm{P}<0.05)$ different according to Tukey test.

Table 4 demonstrates that the flowering period of local sorghum from Belu was not much affected by the salinity level treatment. The longest flowering period of tested sorghum genotypes was observed on plants grown at a salinity level of $12 \mathrm{mmos} \mathrm{cm}^{-1}$, which differed significantly $(\mathrm{P}<0.05)$ from that of the control (without salt treatment). Local sorghum from Sabu-Raijua was able to achieve their generative stage when they were planted on soil with a salinity level of 0-6 mmos $\mathrm{cm}^{-1}$, however, at higher salinity levels, the plants died before reaching their generative phase. Furthermore, all flowering plants were also gradually wilted and died without producing seed. The flowering date of Numbu grown on soil with salinity levels 6-8 mmos $\mathrm{cm}^{-1}$ was significantly shorter than that of the control treatment, but at higher salinity levels, the plants died before reaching their flowering stage.

Local sorghum from Belu grown on Vertisol with salinity levels of 6-8 mmos $\mathrm{cm}^{-1}$ produced significantly $(\mathrm{P}<0.05)$ lower dry seed weight as compared to control. None of the plants of this sorghum genotype was observed to produce seed when they were grown at salinity level

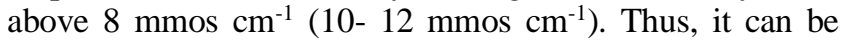
stated that the local sorghum from Belu has a moderate level of salinity tolerance. Local sorghum from SabuRaijua did not produce seed at all. After flowering, the plants of this genotype gradually dried out permanently and died before producing seed. Therefore, it can be stated that the local sorghum from Sabu-Raijua was susceptible to saline soil. Meanwhile, the Indonesian released superior variety Numbu exhibited a moderate level tolerance to saline soil. This sorghum variety was able to grow and produced seeds up to the level of salinity $8 \mathrm{mmos} \mathrm{cm}^{-1}$. 
Based on the present research findings, we concluded that: (i) Salinity level and sorghum genotype significantly affected the plant height, number of leaves, flowering date and dry seed weight of sorghum. (ii) Local sorghum from Belu and Numbu variety were moderately tolerant to saline soil. (iii) Local sorghum from Sabu-Raijua was susceptible to saline soil.

\section{ACKNOWLEDGEMENTS}

The research was funded by the Directorate General of High Education, Ministry of Research, Technology and Higher Education, Indonesia. The authors also thank all technicians of the Soil Chemical Laboratory of Universitas Nusa Cendana, Kupang, Indonesia for their excellent assistance during the laboratory observations.

\section{REFERENCES}

Batha YJ. 2003. The effect of various rice ash dosages applied on saline soil on the salinity level and yield of mustard (Brassica juncea L). [Hon. Thesis]. Faculty of Agriculture, Universitas Nusa Cendana, Kupang. [Indonesian]
BPS Kabupaten Belu. 2012. Badan Pusat Statistik. Belu. BPS Kabupaten Belu, Kefamenanu. [Indonesian]

BPS Kabupaten Sabu Raijua. 2013. Badan Pusat Statistik. Sabu-Raijua. BPS Kabupaten Sabu Raijua, Sabu. [Indonesian]

Darmawijaya MI. 1990. Soil Classification. Universitas Gadjah Mada, Yogyakarta. [Indonesian]

FAO 1985. Irrigation Methods. Land and Water Development Division. Irrigation Water, FAO, Rome, Italy.

FAO 2005. Fao Field Guide: 20 Things to Know about the Impact of Salt Water on Agricultural Land in Aceh Province. United Nations Food and Agriculture Organization, Rome, Italy.

Hasanah U, Taryono, Yudono P. 2010. The effect of Salinity on yield components of fourteen cultivars of sorghum (Sorghum bicolor $\mathrm{L}$ Moench). Faculty of Agriculture, Gadjah Mada University, Yogyakarta. https://jurnal.ugm.ac.id/jbp/article/download/1526/1329. [Indonesian]

House LR. 1985. A Guide to Sorghum Breeding, 2nd edn, International Crops Research Institute for the Semi-Arid Tropics, Patancheru, AP, India

Kleden PB, Ishaq LF, Benggu YI, Duaja W. 2006. Performance of Sorghum under Saline Soil Provided with Organic Mulch and Various Irrigation Time. [Research Report]. Faculty of Agriculture, Universitas Nusa Cendana, Kupang.

Montgomery DC. 2012. Design and Analysis of Experiments, 8th ed. John Wiley \& Sons, Inc., New York

Siregar Z, Bangun MK, Damanik RIM. 2016. Growth response of some varieties of sorghum on saline soil by applying gibberellin. Jurnal Agroekoteknologi 4 (3): 1-7.

Tan KH. 1998. Dasar-dasar Kimia Tanah. Universitas Gadjah Mada Yogyakarta. [Indonesian] 